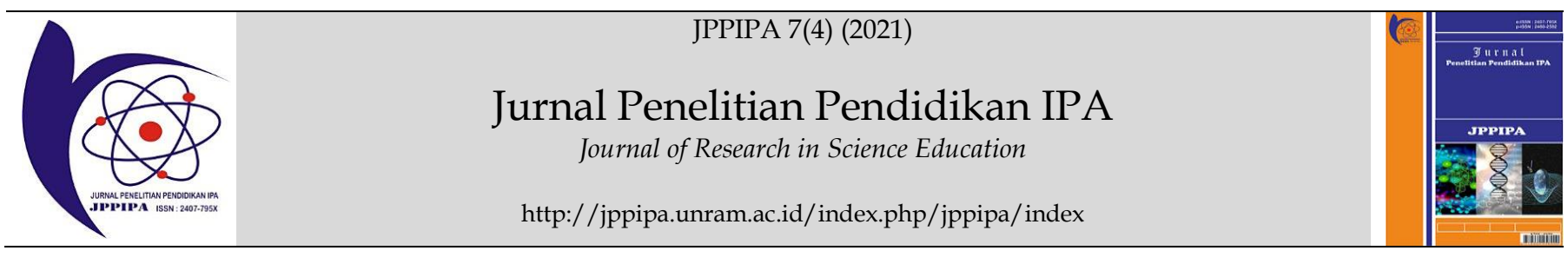

\title{
Improvement of Learning Outcomes, Motivation, and Achievement of Students' Social Skills by Applying Student Teams Achievement Division Cooperative Learning Model through PhET Simulation Media
}

\author{
Wirdatul Jannah ${ }^{*}$, Evendi², Safrida²,Suhrawardi Ilyas²,M. Syukri² \\ ${ }^{1}$ Department of Science Education, Graduate School, Universitas Syiah Kuala, Banda Aceh, Indonesia \\ 2.Department of Physics Education, Teacher Training and Education Faculty, Universitas Syiah Kuala, Banda Aceh, Indonesia
}

DOI: $10.29303 /$ jppipa.v7i4.796

\section{Article Info}

Received: June $15^{\text {th }}, 2021$

Revised: October 10th 2021

Accepted: October 20th 2021

\begin{abstract}
This study aims to improve learning outcomes, motivation, and students' social skills by applying student teams' achievement division cooperative learning models through PhET simulation media. The method used in this study is quantitative. The research used is Quasi-Experimental. Instruments were used in the form of problems, questionnaires and, observation sheets. The results of the study data analysis prove that the average posttest of the experiment class obtained a score of 77.81, while the control class was 71.82 , so that the results obtained in the experimental class were $>75$ or above from the KKM score that has been determined. Furthermore, the analysis of student motivation data proved an increase where the pretest score showed 60.5 and for the posttest results increased by a score of 66.56 and for the results of social skills learners showed an increase in each meeting in each indicator, which showed an excellent category. The conclusions in this study prove that the student teams achievement division cooperative learning model through PhET simulation media can improve learners' learning outcomes, motivation, and social skills.
\end{abstract}

Keywords: STAD type cooperative model; Learning outcomes; motivation; social skills of learners

Citation: Jannah, W., Evendi, E., Safrida, S., Ilyas, S., \& Syukri, M. (2021). Improvement of Learning Outcomes, Motivation, and Achievement of Students' Social Skills by Applying Student Teams Achievement Division Cooperative Learning Model through PhET Simulation Media. Jurnal Penelitian Pendidikan IPA, 7(4), 775-781. doi:https:// doi.org/10.29303/jppipa.v7i4.796

\section{Introduction}

Education is a conscious and planned effort to realize the learning atmosphere and learning process so that learners actively develop their potential to have spiritual-religious power, self-control, personality, intelligence, noble morals, and skills needed for themselves, society, nation, and state (Neolaka, 2017). Efforts are made so that the quality of education can run well, one of them by improving learning.

A good learning process can be created by the management of classes conducted by teachers. It can cause a sense of interest and motivation in the learning process, especially in the field of physics. There are several ways to make learning efficient. One of them is to apply the right models, methods, and learning media for physics learning. The learning process urgently requires a learning environment that supports the learning process of learners to create active learning, effective, innovative, focused on learners, and able learners to achieve the desired results. One of the learning environments that support the progress of learners is the social environment. The social environment is all other people or people who affect us, 
either directly or indirectly (Tamara, 2016). A good social environment can create good abilities, motivation, and skills for learners.

Measuring the ability and skills that exist in learners can be done by using authentic assessments. Authentic aspects are very important to be used so that teachers can know the extent of cognitive achievement abilities (learning outcomes) and skills that learners have achieved. The assessment of learners is done not only by measuring the assessment of cognitive abilities but also the assessment is needed to measure the skills that exist in learners, one of the most important in the learning process is social skills. Social skills are tools that consist of the ability to interact, communicate verbally and nonverbally. The ability will show good behavior and the ability to live good relationships with others that someone uses to be able to behave according to what is expected socially (Simbolon, 2018). Therefore, it is very important to assess the social skills of the K13 curriculum.

Based on observations made at high school 8 Banda Aceh, several problems are targeted for researchers. The problem with the school is that the learning applied so far does not apply learning models that support physical learning. So that makes learners lazy and inactive to follow the learning process because the learning process is not centered on learners. From the interview results obtained, the teacher only applies to learning by teaching lecture methods and only by giving assignments. So that for the abilities and skills that exist in learners cannot be assessed perfectly because they rarely do group discussion learning, teachers carry out learning with material recording, give summary assignments from printed books, and sometimes instruct learners to work on the given problem. It is seen that the role of teachers is more dominating. As a result, learners' interaction is less than optimal because it is only focused on what is given by the teacher, and there are still learners who do not understand the concept of physics. Learners do not understand the symbols of physics, and it is difficult to solve the problems given by the teacher. When learning activities, there is also a gap where learners who have the good academic ability are more active in learning activities both in terms of asking and in expressing opinions, while learners whose abilities are below average tend to choose to be silent for fear of being wrong. The problems that have been described are likely caused due to the mismatch of the learning model applied.

These problems also have an impact on the learning outcomes obtained by learners. Learning results obtained so far many do not achieve from the value of minimum completion criteria that have been set by the school, which is 75 so that teachers often remedial so that the values produced by learners are able to achieve the minimum completion criteria that have been set. Dahnial research (2020) states that the main purpose of organizing learning activities is to teach learners to process and acquire knowledge, skills, and attitudes for themselves. Learners are expected to be motivated and happy to do interesting and meaningful learning activities, and this means that the learning model is very important in relation to learning success. With efforts to overcome the above problems, the learning model is to support learning success, social skills, and learning motivation of learners, so that educational goals can be achieved.

Based on the problems faced by students, one of the learning models that is believed to improve the success of learning, motivation, and social learning skills of learners is the Cooperative Learning Model of Student Teams Achievement Division (STAD).

The Student Teams Achievement Division (STAD) cooperative learning model is one type of cooperative learning model that can be applied to improve social skills. Learners learn in the number of members of each group of 4-5 people heterogeneously. Starting with the delivery of learning objectives, material delivery, group activities, quizzes or evaluations, and group awards (al-Tabany, 2014). In the cooperative learning model, the STAD type is very helpful by focusing on learners to encourage each other and help each other in improving social skills. In the implementation of cooperative learning type STAD, learners apply together to solve a problem given by the teacher, for the role of the teacher himself in this learning process only as a guide and facilitator for learners. In the implementation of the learning process, learners are required to cooperate with each other in groups that have been given, encouraging learners to associate, communicate, and be responsible both individually and in groups. So that indirectly, learners' social skills and motivation will increase in the learning process and later produce good learning outcomes and increase.

To support the STAD-type cooperative learning model, innovation is needed in the learning process. When a person has mastered the concept, then he will have solid thinking development foundations (Awalliyah, 2015). Both can be achieved by learners if there is a physics learning innovation. One such innovation is a learning medium that supports the physics learning process called PhET simulation media. Physics Education Technology (PhET) is a simulation created by (University of Colorado) that contains simulations of physical, biological, and chemical learning for the benefit of learning in class or individual learning (Saputra, 2020). This media can display a material that is abstract and can be explained easily by 
this media so that learners easily understand the material. PhET simulation media helps learners learn to understand the material with object content that is too small, too large, natural events, or very complicated processes (Abdjul, 2019).

Based on the description and presentation of the above problems, a study has been conducted on cooperative models of STAD type through PhET simulation media that can improve learners' learning outcomes, motivation, and social skills. Andrian Research (2020) shows that cooperative learning type STAD positively influences or can improve learners' motivation, social attitudes, and learning outcomes. The results of research related to Marheni (2020) show that there is an influence of the STAD model on increasing social attitudes. It can be seen during the learning process makes learners more excited in learning, learners are also able to cooperate with their groups, and for learning outcomes can be seen when the learning process takes place, students are very enthusiastic and excited in the following learning. According to Armadi (2020), based on the results of research conducted, cooperative learning type STAD can improve learners' activities and learning outcomes. The teaching and learning process takes place effectively, the learning activities of learners in the classroom are very good with high learning motivation.

\section{Method}

The methods used in this research are quantitative methods. The research used is Quasi-Experimental with Type Control Group Pretest Posttest Design. The study involved two classes, the experimental class and the control class. Both classes were given different treatments that were taken randomly. The design of this study can be seen in Table 1 .

Table 1. Research Design

\begin{tabular}{llll}
\hline Subject & Pretest & Perlakuan & Posttest \\
\hline Experiment & $\mathrm{O}_{1}$ & $\mathrm{X}_{1}$ & $\mathrm{O}_{3}$ \\
Control & $\mathrm{O}_{2}$ & $\mathrm{X}_{2}$ & $\mathrm{O}_{4}$ \\
\hline & & \multicolumn{3}{c}{ (Sugiyono, 2018) }
\end{tabular}

Information:

$\mathrm{O}_{1}=$ Pretest in an experimental class

$\mathrm{O}_{2}=$ Pretest in control class

$\mathrm{O}_{3}=$ Posttest on an experimental class

$\mathrm{O}_{4}=$ Posttest on control class

$\mathrm{X}_{1}=$ Application of Learning cooperative learning model type STAD

$\mathrm{X}_{2} \quad$ = Learning by applying a non-cooperative model

The population in this study was all students of class X IPA in Senior High School 8 Banda Aceh, which amounted to 95 learners from 3 classes. Research sample determination technique using a purposive sampling technique. Sampling is done based on the final grades of the exam held by each class in semester one, then compared to choose a class that has learning outcomes with the same grade point average. Based on the review results on the ground, the study sample taken was class X IPA1 as an experimental class and class X IPA2 as a control class. The number of students of both classes is 32 people in the experiment class and 33 people in the control class.

The instruments used in this study are a matter of knowing the learning outcomes, motivational questionnaires, and observation sheets of students' social skills. The data collection procedure is carried out by sharing pretest and motivation pretest questionnaires before applying the learning treatment. Observers will carry out observation sheets during the learning process, then at the end of learning, followed by the provision of posttes motivational posttest questionnaires in the experimental class. While in the control class, they are given a pretest problem before the start of learning and at the end of the teaching given posttest questions. The data analysis techniques in this study used N-gain equations, normality tests, homogeneity tests, t-tests, and Likert scales.

\section{Result and Discussion}

In the process of learning learning learning is one of the most important things. The goal is to know the achievements obtained by learners after the learning process. Learning results can be seen from the acquisition of pretest and posttest scores that have been given to learners. To pretest at the beginning of learning, the goal is to know the initial knowledge of learners before doing the teaching and learning process on simple harmonic vibrational material in both experimental and control classes. The pretest scores obtained by learners in the experiment class with controls were 29.19 and 28.48. The acquisition showed the average pretest score of both the experimental and control classes was still low. This explains that the knowledge of learners on simple harmonic vibration meters in the category is still low. While posttest is done at the end of learning to see how much increase learners' knowledge after the teaching and learning process takes place. The average percentage posttest score of the experimental class with controls was 77.81 and 71.82. Judging from the score, both classes experienced improvements in learners' knowledge, but in the experiment class showed a greater increase compared to the control class. This proves that the learning process using a cooperative model of STAD type through PhET simulation media can make learning outcomes in learners better. The statement is in accordance with the opinion of Haris et al. (2018), 
which states that the STAD learning model with a virtual simulation of PhET is better with increased learners' learning outcomes. Widyaningsih (2018) revealed that PhET media is more effectively used in the learning process and produces learning outcomes that show good categories.
Furthermore, to find out the difference in results between the experimental and control classes, the test will be analyzed two different on average in both classes. The following are the results obtained from the test of two differences in the average learning outcomes of learners. Then more clearly can be seen in Table 2 .

Table 2. Difference in average pretest learners' learning outcomes in experimental classes and control classes

\begin{tabular}{lllll}
\hline No & Class & Normality & Homogeneity & Significance \\
\hline 1 & Experiment & $\begin{array}{l}\text { if Sig. }>0.050(0.189)<(0.050) \text { (normal } \\
\text { distribution) }\end{array}$ & $\begin{array}{l}F_{\text {hit }}<F_{\text {tab, }}(0,567)<(0,050) \\
\text { (homogen) }\end{array}$ & $\begin{array}{l}t_{\text {hit }}<t_{\text {tab }}(2,831)<(1,671) \\
\text { (there is a significant } \\
\text { difference) }\end{array}$ \\
& Control & $\begin{array}{l}\text { if Sig. }>0.050(0.2)<(0.050) \text { (normal } \\
\text { distribution) }\end{array}$ & & (n)
\end{tabular}

Table 1 shows the results of the analysis that posttest scores in both classes were obtained $t_{\text {count }}$ $(2.831)>t_{\text {tabble }}(1,671)$, so it can be concluded that there is a significant difference between the two classes, namely in the experimental and control classes. The difference is evident in classes that received treatment using a cooperative model of STAD type through PhET simulation media during the learning process with a higher score.

After knowing the results of the analysis of learners' learning outcomes, then do an analysis of learning outcomes assessment using N-gain. The goal is to find out the improvements that occur in the experimental and control class. Full data related to the $\mathrm{N}$-gain test can be seen in Figure 1.

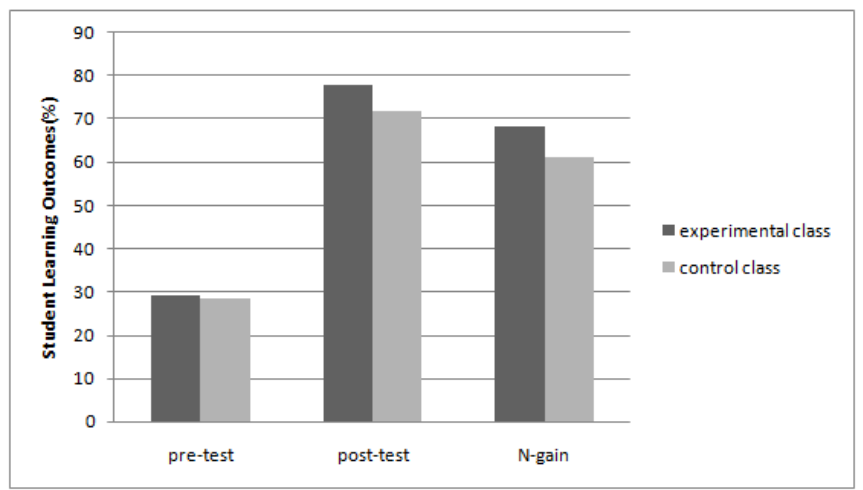

Figure 1. Improved learners' learning outcomes

Figure 1 shows overall that learners learn outcomes in experimental and control classes. Improvements in the experimental class using the STAD-type cooperative model through PhET simulation media were higher than in the control class. Based on observations made during the learning process, it can be seen that learners are more active and enthusiastic because learners participate more in the learning process compared to control classes.

The increase in learners' learning outcomes in higher experiment classes is due to the full opportunity for each learner to develop their knowledge when conducting learning activities using a cooperative model of STAD type and develop their respective skills when practicum based on LKPD-based media simulation PhET gave at each meeting so that for learning results obtained quite well and increased compared to control classes that are not applied with the STAD-type cooperative learning model. Statements that support improving learning outcomes due to the application of this model expressed by Mulyani (2021) through STAD-type cooperative learning methods can improve learners' learning outcomes in cognitive, affective, and psychomotor aspects at each meeting. Rostika (2020) added that using the Student Teams Achivement Division (STAD) method has increased so that learners' level of understanding and learning outcomes also increases because learners experience each learning activity themselves.

After analyzing the results of learning, it is continued with the analysis of the motivation of learners. The goal is to determine the extent of the increased motivation obtained by learners with implementing the STAD-type cooperative learning model through PhET simulation media. Increased motivation of learners is obtained based on the difference in value before and after learning. Data on the results of learners' learning motivation can be seen in Table 3.

Table 3. Data on student motivation results

\begin{tabular}{llllll}
\hline Class & Normality & \multicolumn{3}{c}{ Homogeneity } & Significance \\
\cline { 2 - 4 } & Pretest & posttest & Pretest & posttest & \\
\hline Experiment & 60,50 & 66,56 & 0,726 & 0,682 & $t_{\text {hit }}<\mathrm{t}_{\text {tab }}$ \\
& & & & & $(15,59)<(1,671)$ (there is a significant difference) \\
\hline
\end{tabular}


Based on Table 3, there is an increase in learners' learning motivation before and after learning. The results of learners' motivation before learning were obtained on average by 60.50 , and the results after learning increased by 66.56. Increased learning motivation of learners can also be seen in Figure 2.

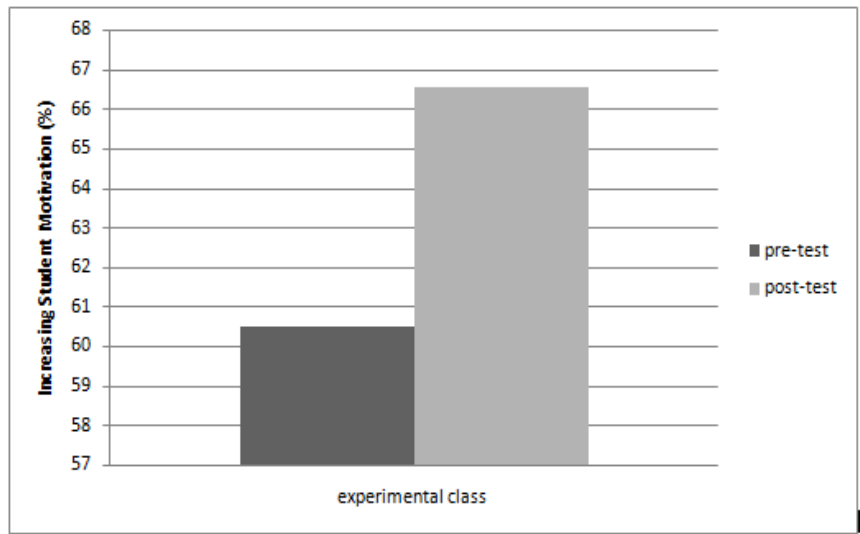

Figure 2. Increased motivation of learners

Figure 2 shows that the results of increased learning motivation of learners between before and after learning. Furthermore, to find out the increase in learning motivation, then tested hypotheses using the ttest. The results of the study analysis obtained $t_{\text {count }}$ of 15.59 while $t_{\text {tabble }}$ with a confidence level of 0.05 , the degree of freedom dk $65-2=63$ is 1.671. This shows that thitung>ttabel so that the hypothesis that reads the application of cooperative models of STAD type through PhET simulation media can increase the learning motivation of "accepted" learners. This happens because the application of STAD-type cooperative models through PhET simulation media can make learners motivated.

Based on the results of observations, learners are very enthusiastic in following the learning process, actively discussing or asking teachers if things are still not understood. Activities from the STAD-type cooperative model greatly train the learning motivation of learners to be even better. Similar research has also been conducted by Andrian (2020) states that cooperative learning type STAD has an effect on motivation or where the results of the analysis show that there is an interaction between motivation and cooperative Type STAD. Armadi (2020) added that the teaching and learning process takes place with cooperative learning being effective, and the learning activities of learners in the classroom are very good with high learning motivation. Learners already have the courage to argue and are able to find answers in discussion with colleagues and one group. Furthermore, Tendrita (2020) revealed that the cooperative learning type STAD, every learner gets the opportunity to communicate his ideas in helping other learners who are experiencing difficulties in their group.

Furthermore, after conducting a learning motivation analysis of learners conducted social skills analysis, the goal is to find out the achievement of students' social skills with the application of STADtype cooperative models through PhET media. The social skills in the study were measured using social skills observation sheets organized based on indicators. The assessment sheet will be given to each observer in each group that has been divided by teachers consisting of several learners. Observers conduct assessments on learners at each learning meeting. A concise analysis of social skills improvement can be seen in Table 4 .

Table 4. Learner skills data

\begin{tabular}{llll}
\hline Indicator & \multicolumn{3}{l}{ Meeting } \\
\cline { 2 - 4 } & I & II & III \\
\hline Skills to work together & 57.85 & 64.85 & 79.85 \\
Communication skills & 62.4 & 71 & 81.2 \\
Academic skills & 64.75 & 75.25 & 87.75 \\
Self-regulating skills & 65 & 77 & 88.33 \\
Friendship skills & 64.1 & 73.28 & 88.42 \\
\hline
\end{tabular}

Based on Table 4, the acquisition of scores based on indicators in each meeting obtained by learners can be seen. The score obtained at each meeting and viewed from each indicator shows an increase in each meeting from the first meeting to the second meeting and from the second meeting to the third meeting. Results show an increase from the category enough to reach the high category. For improvement, the results of students' social skills can briefly be seen in Figure 3.

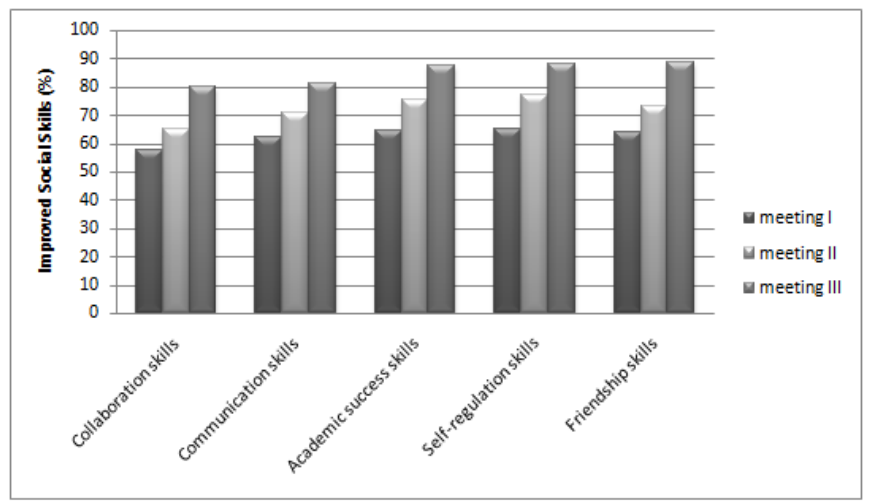

Figure 3. Comparison of the value of students' social skills at each meeting based on indicators

The results from Figure 3 show that overall, learners' social skills in the experiment class improved in each meeting and produced excellent categories when applied learning using a cooperative model of STAD type through PhET simulation media. Similar research has also been conducted by Maheni (2020), 
stating that the increasing social attitude of learners can be seen during the learning process by applying the STAD model to make learners more excited in learning. Learners are also able to cooperate with their groups. This is in line with the results of Andrian's research (2020), stating that cooperative learning can improve the social attitude of learners.

\section{Conclusion}

Based on the research result, it can be conclude tha the application of STAD-type cooperative models through PhET media improves learning outcomes, motivation, and achievement of students' social skills in harmonic vibrational materials in Banda Aceh High School 8. The analysis of learning data results proved that the average posttest of the experiment class was obtained a score of 77.81 while the control class was 71.82. The results obtained in the experimental class were $>75$ or above from the minimum completion criteria score determined. Furthermore, the analysis of student motivation data proved an improvement with the implementation of the STAD-type cooperative learning model where the pretest score showed 60.5 and for the posttest results increased with a score of 66.56, and for the results of social skills, learners showed an increase in each meeting on each indicator of social skills, which showed excellent categories. Based on the results of the analysis that has been done, it can be concluded that the average experimental class learner applied with the STAD type cooperative learning model is more improved than in the control class applied with conventional models.

\section{Acknowledgments}

Thank you to the leadership, teaching staff, and teachers of physics studies at Senior High School 8 Banda Aceh, who have provided opportunities and service facilities during research, and thanks to the guidance lecturers who have guided in completing this article.

\section{References}

Abdjul, T., \& Ntobuo, N.E. (2019). Penerapan media pembelajaran virtual laboratory berbasis phet terhadap hasil belajar siswa pada materi gelombang. Jurnal Pendidikan Fisika Tadulako Online (JPFT), 7(3). Retrieved from: http://jurnal.untad.ac.id/jurnal/index.php/EPF $\mathrm{T} /$ article/view/14583 [Indonesian]

Andrian, D., Wahyuni, A., \& Ramadhan, S. (2020). Pengaruh pembelajaran kooperatif tipe STAD terhadap peningkatan hasil belajar, sikap sosial, dan motivasi belajar. Jurnal Inovasi Matematika (Inomatika), 2(1), doi: https://doi.org/10.35438/inomatika.v2i1.163 [Indonesian]

Armadi, S. (2020). Model pembelajaran kooperatif dalam peningkatan motivasi dan partisipasi belajar. Jurnal Intelegensia, 5(2). Retrieved from: http://intelegensia.org/index.php/intelegensia $\angle$ article/view/148 [Indonesian]

Awalliyah, S. Siahaan, P., Nugraha, M.G., \& Kirana, K.H. (2015). Hubungan keterampilan proses sains dengan penguasaan konsep serta kaitannya dengan gaya kognitif field dependent-field independent. Jurnal Pengajaran MIPA, 20(2). doi:https://doi.org/10.18269/jpmipa.v20i2.3624 2 [Indonesian]

Dahnial, I. (2020). Penerapan model pembelajaran picture and picture terhadap pendidikan lingkungan hidup (PLH) untuk meningkatkan komptensi guru di SD negeri sekecamatan STABAT. Jurnal Berbasis Sosial, 1(1). Retrieved from:

https://jurnal.stkipalmaksum.ac.id/index.php/j bs/article/view/68 [Indonesian]

Haris. R., Suherman. A., \& Darman. D.R. (2018). Penerapan model STAD berbantu simulasi virtual PhET pada untuk meningkatkan hasil belajar kognitif siswa sma kelas XI. Prosiding Seminar Nasional Pendidikan FisikaUntirta, 1(1). 5963. Retrieved from: https://jurnal.untirta.ac.id/index.php/sendikfi/ article/view/9667 [Indonesian]

Marheni, N., Jampel, I., \& Suwatra, I. (2020). Pengaruh Model Pembelajaran Kooperatif Tipe (STAD) Terhadap Sikap Sosial dan Hasil Belajar IPA. Jurnal Penelitian dan Pengembangan Pendidikan, 4(3), 351-361. doi:http://dx.doi.org/10.23887/jppp.v4i3.27414 [Indonesian]

Mulyani. S. (2021). Peningkatan hasil belajar siswa kelas IV SD Negeri Karangwuni 03 dengan model pembelajaran Kooperatif tipe STAD. Jurnal Inovasi Pendidikan dan Teknologi Informasi, 2(1). Retrieved from http://ejournal.stkipmmb.ac.id/index.php/JIPTI/article/view/451 [Indonesian]

Neolaka, A.G. (2017). Landasan Pendidikan. Depok: Kencana. [Indonesian]

Rostika. D. (2020). Penerapan model pembelajaran kooperatif tipe STAD untuk meningkatkan hasil belajar kimia. Journal of Educational Development, 1(2), doi: http://dx.doi.org/10.5281/zenodo.4004041. [Indonesian] 
Saputra, R., Susilawati., \& Verawati, S. P. 2020. Pengaruh media simulasi PhET terhadap hasil belajar fisika. J. Pijar MIPA, 15(2). doi: http://dx.doi.org/10.29303/jpm.v15i2.1459 [Indonesian]

Simbolon. E.T. (2018). Pentingnya keterampilan sosial dalam pembelajaran. Jurnal Christian Humaniora. 2(1). doi: https://doi.org/10.46965/jch.v2i1.108 [Indonesian]

Tamara, R.M. (2016). Peranan lingkungan sosial terhadap pembentukan sikap peduli lingkungan peserta didik di SMA Negeri Kabupaten CIANJUR. Jurnal Pendidikan Geografi, 16(1). doi: https://doi.org/10.17509/gea.v16i1.3467 [Indonesian]

Tendrita, M., \& Sari. A.P.P. (2020). Penerapan model pembelajaran kooperatif tipe student team achievement divisions (STAD) dipadu RQA Berbasis Lesson Study untuk meningkatkan motivasi belajar dan kemampuan komunikasi mahasiswa Pendidikan Biologi Universitas Negeri Malang. Jurnal Pendidikan Biologi, 5(1). doi: https://doi.org/10.34289/bioed.v5i1.1427 [Indonesian]

Widyaningsih. S. W., \& Yusuf Irfan. 2018. Penerapan simulasi PhET terhadap hasil belajar mahasiswa pada mata kuliah Fisika II di Program Studi Ilmu Kelautan Universitas Papua. Jurnal Berkala Ilmiah Pendidikan Fisika, 6(2). doi: http://dx.doi.org/10.20527/bipf.v6i2.4908

[Indonesian] 